University of Pennsylvania Carey Law School

Penn Carey Law: Legal Scholarship Repository

Faculty Scholarship at Penn Carey Law

2016

\title{
Motivating Without Mandates: The Role of Voluntary Programs in Environmental Governance
}

\author{
Cary Coglianese \\ University of Pennsylvania Carey Law School \\ Jennifer Nash \\ Harvard Business School
}

Follow this and additional works at: https://scholarship.law.upenn.edu/faculty_scholarship

Part of the Administrative Law Commons, Business Law, Public Responsibility, and Ethics Commons, Environmental Policy Commons, Law and Economics Commons, Law and Politics Commons, Law and Society Commons, Policy Design, Analysis, and Evaluation Commons, and the Public Administration Commons

\section{Repository Citation}

Coglianese, Cary and Nash, Jennifer, "Motivating Without Mandates: The Role of Voluntary Programs in Environmental Governance" (2016). Faculty Scholarship at Penn Carey Law. 1647.

https://scholarship.law.upenn.edu/faculty_scholarship/1647

This Book Chapter is brought to you for free and open access by Penn Carey Law: Legal Scholarship Repository. It has been accepted for inclusion in Faculty Scholarship at Penn Carey Law by an authorized administrator of Penn Carey Law: Legal Scholarship Repository. For more information, please contact PennlawIR@law.upenn.edu. 


\title{
Motivating Without Mandates: The Role of Voluntary Programs in Environmental Governance
}

\author{
Cary Coglianese \\ Edward B. Shils Professor of Law and Professor of Political Science; \\ Director, Penn Program on Regulation \\ University of Pennsylvania Law School \\ Jennifer Nash \\ Director, Business and Environment Initiative \\ Harvard Business School
}

\begin{abstract}
$\underline{\text { Abstract }}$
For the last several decades, governments around the world have tried to use so-called voluntary programs to motivate private firms to act proactively to protect the environment. Unlike conventional environmental regulation, voluntary programs offer businesses flexibility to adopt cost-effective measures to reduce environmental impacts. Rather than prodding firms to act through threats of enforcement, they aim to entice firms to move forward by offering various kinds of positive incentives, ranging from public recognition to limited forms of regulatory relief. Despite the theoretical appeal of voluntary programs, their proper role in government's environmental toolkit depends on the empirical evidence of how these programs work in practice. This paper offers a comprehensive empirical overview of voluntary programs' design and impact. It shows that not all voluntary programs are the same. Rates of business participation in voluntary programs depend on a variety of factors, including both how these programs are designed as well as, importantly, what kinds of relevant background regulatory threats may loom for business. Although governments and policy advocates sometimes urge voluntary programs as a substitute for conventional government regulation, it appears that the most effective voluntary programs depend on a robust backdrop of community pressure and regulatory threats. Studies that find these programs yield statistically discernible effects on firm behavior generally find only substantively small impacts, suggesting that at best voluntary programs can serve as a modest supplement to government regulation.
\end{abstract}

Keywords

Voluntary environmental programs, innovation, incentives, ISO 14001, selfregulation, private regulation, evaluation 


\title{
Motivating without Mandates: The Role of Voluntary Programs in Environmental Governance
}

\author{
Cary Coglianese ${ }^{*}$ and Jennifer Nash ${ }^{* *}$
}

Is it possible for governments to foster better environmental performance simply by encouraging firms to take steps to do so, without ever requiring them to do so? Since the mid-1980s, governments around the world have been attracted to the potential for voluntary environmental programs to coax private sector firms to reduce pollution and save natural resources. These programs attempt to change private sector behavior not by requiring compliance with mandatory regulations, but by offering often modest incentives, such as access to information and positive public recognition. They might even be said to try to nudge business managers toward socially desired behavior without imposing a heavy hand of governmental control. $^{1}$

Voluntary programs hold great appeal. State and federal governments in the United States operate perhaps as many as 200 voluntary environmental programs, and upwards of 300 exist throughout the European Union. ${ }^{2}$ In the United States, the federal Environmental Protection Agency (US EPA) has created a veritable smorgasbord of such programs, ranging from voluntary product labeling systems, such as its well-known Energy Star program that promotes energy-efficient product design, ${ }^{3}$ to public recognition programs, such as US EPA's highly-trumpeted "33/50" program that in the 1990s gave public recognition to companies that made commitments to reduce releases of toxic chemicals. ${ }^{4}$ For many years, the US EPA's flagship voluntary program was its National Environmental Performance Track that offered public recognition and modest regulatory relief to facilities that made several "beyond-compliance" environmental commitments. ${ }^{5}$

The theoretical appeal of governmental voluntary environmental programs is seductive. We begin this chapter, therefore, by summarizing the theoretical advantages of voluntary programs, but we also consider some of their potential limitations. After showing how the design of these programs can vary greatly, we review what researchers know about how effective these programs can be in

\footnotetext{
* Edward B. Shils Professor of Law and Professor of Political Science; Director, Penn Program on Regulation, University of Pennsylvania Law School.

** Director, Business and Environment Initiative, Harvard Business School.

A revised version of this working paper is forthcoming in Lee Paddock and Robert Glicksman, eds., Environmental Decision Making (Edward Elgar).

${ }^{1}$ Thaler and Sunstein (2008)

2 Darnall and Carmin (2005) 76; Delmas and Keller (2005) 91. Governments in developing countries increasingly operate voluntary programs as well. Blackman (2010).

${ }^{3}$ US EPA (2015).

${ }^{4}$ Coglianese and Nash (2014) 70-80.

${ }^{5}$ Ibid.
} 
reducing environmental degradation and risks. Voluntary programs' effectiveness depends primarily on two factors: the number of firms that will participate in them and the average effect for each participant. ${ }^{6}$ In addressing the first of these, we consider what we know about why firms decide to join voluntary programs: principally, to stave off the costs of regulatory compliance, appeal to customers and other external interests, and fulfill managers' own values. These motivations, we show, have proven insufficient to persuade any large fraction of polluting firms to join voluntary programs, let alone invest in major, costly environmental improvements. As a result, the impacts of voluntary programs are mixed, with at best some evidence of small, positive results from a few programs. Surprisingly, given voluntary programs' seductive appeal of motivating firms without costly mandates, their performance in practice is such that their role can amount to little more than a minor supplement to mandatory regulations. Research to date indicates that voluntary programs work best when government possesses the capacity, and expends the resources needed, to verify members' claims of voluntary accomplishments - and ultimately when mandatory regulation looms in the background as a viable threat.

\section{Theoretical advantages and disadvantages}

The idea of motivating without mandates holds considerable appeal because environmental regulation and its enforcement are costly - not just for industry, but also for government. The US EPA's budget included more than $\$ 790$ million for compliance and enforcement activities in FY 2015, approximately 10 percent of its budget overall. $^{7}$ The costs of complying with environmental regulations-borne by private sector firms as well as governments at the local, state, and federal levelshas been estimated at $\$ 200$ billion annually in the United States alone. ${ }^{8}$ Since regulations can sometimes be over-inclusive - one size hardly always fits allalternative approaches to environmental governance promise significant cost savings. After all, voluntary programs are voluntary. Firms can choose their own means of environmental control, seeking the lowest cost strategies to improve the environment.

Voluntary programs also purportedly cost less for government agencies to implement, as firms can be required to come forward to provide documentation of their voluntary accomplishments. Especially during periods of political gridlock and fiscal austerity, these programs constitute an attractive option for addressing perceived gaps in the existing regulatory system, whether to address the problems of climate change, toxic contamination, natural resource shortages, or species extinction.

Voluntary programs also promise to reduce the level of conflict between business and government that seems to pervade most regulatory fields today,

\footnotetext{
${ }^{6}$ Borck and Coglianese (2009).

${ }^{7}$ US EPA (2014) 9.

${ }^{8}$ Fiorino (2006) 1. Fiorino bases this estimate on US EPA (1990). It represents annual costs in the United States in 2000.
} 
fostering an ethic of shared responsibility for protecting the environment. ${ }^{9}$ Because voluntary programs merely suggest, rather than dictate, activities that firms can take to protect the environment, they have won widespread support from both governments and industries, with support often cutting across political ideologies. Governments can also often create voluntary programs through administrative action, foregoing the lengthy and contentious process of legislative review and approval. ${ }^{10}$

In addition, some proclaim that voluntary programs can encourage privatesector managers to think critically about ways to improve their environmental performance, prompting discovery of environmental protection activities that are in their self-interest. ${ }^{11}$ They are opportunities, in other words, for the promotion of win-win solutions to environmental sustainability. They can leverage the deep, firsthand knowledge that private-sector managers have about where the greatest or most cost-effective opportunities for environmental improvement lie. ${ }^{12}$ Many programs also create opportunities for information sharing among firms, as well as with government, thereby facilitating the diffusion of best environmental practices. $^{13}$

These theoretical benefits of voluntary programs are clearly significant. Of course, they are also counter-balanced with some potential limitations and disadvantages too. Even if voluntary programs are relatively less costly for government to administer, if conventional regulatory programs are in fact more effective, then any investments in voluntary programs might be ill-advised. After all, the governmental costs of voluntary programs are not trivial. In 2006, for example, US EPA spent approximately $\$ 352$ million on program advertising and recruitment, application processing, grants, and overall administration of its voluntary programs. ${ }^{14}$

Some worry that voluntary programs not only divert fiscal resources but also dampen the political case for more effective policies. They could create an impression that important problems are being addressed in a win-win fashion, thus taking the pressure off politicians to make tough regulatory decisions. At a more operational level, voluntary programs might also misallocate inspection resources as they demand that government officials give more of their time and attention to responsible firms instead of targeting for scrutiny those firms that pose the greatest health and environmental risks. ${ }^{15}$ Worse yet, if they are not carefully designed and administered, voluntary programs might also perversely recognize and reward the wrong firms, putting government in a role of supporting industry "greenwashing.", 16

\footnotetext{
${ }^{9}$ Fiorino (2006) 20-21, discussing the benefits of a new type of environmental regulation exemplified by the US EPA's National Environmental Performance Track.

${ }^{10}$ Coglianese and Nash (2014) 10.

${ }^{11}$ Fiorino (1999) 449; Orts (1995); Esty and Winston (2006).

${ }^{12}$ Coglianese and Nash (2001) 10.

${ }^{13}$ Coglianese and Nash (2014) 85.

${ }^{14}$ US EPA Office of Inspector General (2006) 5.

${ }^{15}$ Nash (2005) 270.

${ }^{16}$ Delmas and Keller (2005).
} 


\section{Variability among programs}

These theoretical benefits and limitations of voluntary programs point to the need for empirical research on what these programs accomplish in practice. Any such research must first begin with understanding how these programs are designed. It is true, of course, that all voluntary programs share a common purpose: to encourage firms and other entities to improve their environmental performance through incentives rather than regulatory threats. But they also differ widely in the way they are designed and the types of incentives they offer.

Voluntary programs can be grouped into three main types: public voluntary programs (where governments define program requirements and invite firms to join), negotiated agreements (where firms and governments jointly define environmental requirements through negotiation), and unilateral agreements (where trade associations or firms themselves define requirements for their environmental activities, without any direct input from government). ${ }^{17}$ Public voluntary programs and negotiated agreements are the primary focus of this chapter, as we are concerned with understanding better the role of voluntary programs in government's environmental policy portfolio.

Governments often create voluntary programs to address environmental problems not yet covered by regulation. Some of the first voluntary programs, for example, targeted unregulated uses and releases of toxic chemicals from manufacturing firms. ${ }^{18}$ And today, many programs encourage reductions in greenhouse gases that have escaped regulatory control. ${ }^{19}$ Some programs encourage facilities to improve overall environmental performance by adopting environmental management systems, which are not currently required in most jurisdictions. ${ }^{20}$ Other programs, such as Energy Star in the United States, focus on adoption of energy saving technologies.

Governments offer a range of incentives to encourage firms to join voluntary programs. The most common incentive is access to information, whether through opportunities for peer-to-peer sharing, meetings with high-ranking

\footnotetext{
${ }^{17}$ Segerson and Li (2000) 275.

${ }^{18}$ US EPA launched 33/50 in 1990 to encourage firms voluntarily to reduce releases of 17 designated chemicals by 33 percent by 1992 and by 50 percent by 1995, relative to 1988 levels. The Canadian Environmental Agency created a similar program, Accelerated Reduction/Elimination of Toxics, in the early 1990s. Chittock and Hughey (2011) 544545; Antweiler and Harrison (2007).

${ }^{19}$ US EPA currently operates more than 25 voluntary programs encouraging industry and the public sector to reduce energy consumption and emissions of greenhouse gases: http://www.epa.gov/climatechange/EPAactivities/voluntaryprograms.html. British and Danish voluntary programs to reduce greenhouse gases are described, respectively, in Glachant and de Muizon (2007) and Krarup and Millock (2007).

${ }^{20}$ The European Union Eco-Management and Audit Scheme is a prominent example. See http://ec.europa.eu/environment/emas/index_en.htm.
} 
officials, or technical assistance to members. ${ }^{21}$ Some programs offer grants to encourage new environmental management techniques. Some European governments provide tax rebates to firms that voluntarily agree to improve their energy efficiency. ${ }^{22}$

For many programs, the primary incentive is governmental recognition that the business is an environmental 'leader'. ${ }^{23}$ Leadership recognition sometimes takes place through affirmative publicity that hails specific businesses on agency websites and press releases. It also comes about by authorizing marketing logos and product labeling. Increasingly, governments use public voluntary programs to encourage manufacturers to improve the environmental performance of their products - the incentive for programs of this type is usually a product label. ${ }^{24}$

Some voluntary programs also offer regulatory benefits such as reduced regulatory oversight or exemption from certain reporting or other administrative requirements. ${ }^{25}$ The US National Environmental Performance Track program, for example, applied more relaxed standards under hazardous waste laws to qualifying facilities and also promised these facilities a reduction in enforcement scrutiny. ${ }^{26}$

Voluntary programs vary widely with respect to other aspects of their design. Some programs set more ambitious requirements for entry and ongoing participation than others. Some monitor participants' adherence to program commitments more closely than others, sometimes through third-party auditing. Others require that members disclose information about their performance or impose sanctions, including removal from the program, on those who fall behind. Of course, a number of programs have only 'weak' entry requirements and soft oversight. $^{27}$

The variations in design elements make it difficult to generalize about all voluntary programs. The way they are designed can be expected to make some more effective than others. But what exactly does it mean for a voluntary program to be effective? Effectiveness is generally understood to be a function of two principal factors: the number of firms that choose to participate, and the average effect for each participant, as shown in Figure $1 .{ }^{28}$ Unless the average effect is profound, the ability of these programs to attract members will be a critical variable. If voluntary programs are little known or do not induce many firms to change their

\footnotetext{
${ }^{21}$ Lyon and Maxwell (2007) 727.

${ }^{22}$ Krapaup and Millock (2007) 86.

${ }^{23}$ Lyon and Maxwell (2007) 727; Coglianese and Nash (2014) 28.

${ }^{24}$ US EPA Office of Inspector General (2006) 4.

${ }^{25}$ Coglianese and Nash (2014) 29.

${ }^{26}$ Ibid 30.

${ }^{27}$ Prakash and Potoski (2006) 54-62.

${ }^{28}$ Coglianese and Nash (2014). Borck and Coglianese (2009) note the theoretical possibility that voluntary programs may also have spillover effects, shaping the environmental practices of firms that do not participate as members. However, since these are at best weak, subsidiary effects (Coglianese and Nash (2014) 84 n 529), we focus here on the primary effects, which also have been the most widely studied.
} 
behavior to qualify for entry into the program, then these programs will at best only have marginal overall effects on the environment.

Figure 1. Factors determining the effectiveness of voluntary programs

$$
\text { Effectiveness }=\left(\begin{array}{l}
\text { Number of } \\
\text { participants }
\end{array}\right) \times\left(\begin{array}{l}
\text { Average effect } \\
\text { per participant }
\end{array}\right)
$$

Source: Borck and Coglianese (2009) 310.

Drawing on studies from the United States, Europe, and developing countries, the remainder of this chapter reports what researchers have learned about these two factors-both why some firms choose to participate, and how participation affects their environmental performance.

\section{Why firms join}

Policymakers seeking to design voluntary programs that will have a significant impact need to understand what makes membership appealing to businesses. Researchers have used multiple approaches to explore firms' motivations: theoretical modeling, econometric analysis, and qualitative research.

One reason firms participate in voluntary programs is to stave off or reduce the cost of regulatory compliance. Segerson and Miceli developed modeling that shows how a firm's voluntary actions will increase as the threat of regulation grows. ${ }^{29}$ Compared to mandatory regulation, a voluntary program lowers both environmental protection costs for the firm and transaction costs for the regulator, although the level of environmental protection achieved may also be lower. ${ }^{30}$ Selfinterested firms may use voluntary programs to deter consumer groups from organizing for mandatory controls. ${ }^{31}$ By voluntarily committing to a high level of environmental performance, firms may convince regulators to defer the establishment of mandatory controls. ${ }^{32}$

Empirical evidence generally supports these predictions. Firms that join voluntary programs tend to be larger, have higher levels of toxic releases, and be subject to higher levels of regulation than non-participants. ${ }^{33}$ These are precisely the kinds of firms whose compliance regulators are most likely to scrutinize closely - and who might particularly value the regulatory benefits that voluntary programs provide. These regulatory benefits have included substantive exemptions as well as reduced inspection scrutiny. For example, US EPA granted regulatory relief to firms that joined Project XL, a program in which the agency negotiated agreements with individual firms under which the agency granted regulatory

\footnotetext{
${ }^{29}$ Segerson and Miceli (1998) 128.

${ }^{30}$ Ibid 129.

${ }^{31}$ Maxwell, Lyon, and Hackett (2000) 613.

${ }^{32}$ Lutz and others (2000) 346.

${ }^{33}$ Arora and Cason (1995) 430; Videras and Alberini (2000) 460; Khanna and Damon (1999) 16-17.
} 
exemptions in exchange for the firms providing a demonstrated ability to achieve superior environmental performance through other means. ${ }^{34}$ As already noted, one of the benefits the US EPA offered members of its National Environmental Performance Track program was designation as a low priority for routine federal and state compliance inspections. ${ }^{35}$ Researchers have found that governments inspect members of other voluntary programs less closely than non-members. ${ }^{36}$ Firms that joined the U.S. EPA's 33/50 program, for example, experienced fewer inspections and enforcement actions, even though the program did not explicitly offer that benefit. ${ }^{37}$

In addition to gaining potential advantages in the ways governments regulate, firms also join voluntary programs to appeal to customers and community and environmental interest groups. Firms can benefit from sharing their positive environmental achievements with consumers, customers, and investors, and voluntary programs offer a way of boosting the credibility of their claims. ${ }^{38}$ In this way, participation in voluntary programs helps firms reinforce a reputation for environmental awareness and concern. ${ }^{39}$ Empirical research finds that participating firms are indeed the ones more likely to spend more on advertising and that more highly value customer goodwill, consistent with the expectation that these firms view participation as a way to bolster their public image. ${ }^{40}$ Managers who recognize stakeholder influences as important to their organizations report being more interested in joining voluntary programs. ${ }^{41}$

A firm's decision to join a voluntary program is also shaped by the characteristics of the firm and its managers - in particular, the values and identities of those responsible for determining whether to join a voluntary program. A firm's management style-its "expressed attitudes" about environmental problems, relevant actions, and explanations of its environmental decisions-influence the way managers interpret and act on regulatory requirements and demands from external interests. ${ }^{42}$ Internal characteristics serve as a lens through which managers make sense of what's going on inside and outside their organizations. For some, joining a voluntary program reinforces preexisting environmental leadership roles and attitudes. For others, these programs have little relevance and are viewed as "paperwork" that amounts to little more than "fluff." 43 A study of participants and non-participants in the US EPA's Performance Track found that participants were distinguished by the level of internal management support for voluntary program membership, the degree to which their organizations' identity was linked to

\footnotetext{
${ }^{34}$ Boyd and others (1998) 5.

${ }^{35}$ Coglianese and Nash (2014) 29.

${ }^{36}$ Innes and Sam (2008) 290-291.

${ }^{37}$ Ibid.

${ }^{38}$ Arora and Gangopadhyay (1995); Darnall and Carmin (2005).

${ }^{39}$ Segerson and Li (1999); Lyon and Maxwell (2002).

${ }^{40}$ Arora and Cason (1996); Khanna and Damon (1999).

${ }^{41}$ Darnall and others (2009).

${ }^{42}$ Gunningham and others (2003) 97.

${ }^{43}$ Howard-Grenville and others (2006) 96.
} 
environmental excellence, and the value managers placed on displays of behavior intended for those outside their organizations. ${ }^{44}$

Finally, a firm's decision to join a voluntary program is affected by certain features of the program itself, such as the stringency of its entry criteria and the types of benefits it offers. Researchers have noted a "participation paradox" in which programs that offer the greatest benefits tend to attract the fewest members. This paradox is the result of governments' tendency to set demanding admissions requirements for programs that offer significant rewards - so demanding that few firms appear interested to meet them. ${ }^{45}$ In a 1996 review of US EPA voluntary programs, Davies and Mazurek attributed high participation rates in the agency's $33 / 50$ program to the ease with which firms were able to join, and they noted that efforts to continue the program were unsuccessful when the agency sought to impose additional eligibility criteria on firms. ${ }^{46}$

Most research on why businesses participate in voluntary programs has focused on decisions about "partnership" voluntary programs, ones in which governments specify entry requirements for firms to "join" a select group of recognized businesses. Firms can be expected to participate in other kinds of voluntary programs for similar reasons, although "product certification" voluntary programs offer companies one additional incentive: potential market advantage if consumers value the label available for qualifying products.

Although the US EPA's most well-known product certification program, Energy Star, boasts upwards of 16,000 participating businesses across 70 different product categories, most other voluntary programs attract only a small percentage of eligible firms. Only about 4,100 organizations participate in the European Union's Eco-Management and Audit Scheme, a voluntary program open to any organization worldwide. ${ }^{47}$ At its peak in 2008, the US EPA's Performance Track program attracted about 575 members, out of a potential membership pool of hundreds of thousands of facilities. ${ }^{48}$ In 2006, the combined membership of US EPA's 11 programs geared to reducing greenhouse gases amounted to about 2,900 businesses. ${ }^{49}$ Although several thousand participating companies may seem like a lot, this is actually a tiny fraction of the millions of businesses that operate-and affect the environment-in a country the size of the United States.

\section{How participation impacts environmental performance}

Assessing the impact of voluntary programs on environmental performance presents several methodological challenges. The factors that lead firms to join voluntary programs - sensitivity to regulatory, competitive, and social drivers, as well as distinct internal characteristics - also shape their behavior once they

${ }^{44}$ Coglianese and Nash (2014) 70.

${ }^{45}$ Coglianese and Nash (2014) 80.

${ }^{46}$ Davies and Mazurek (1996) 68.

${ }^{47}$ Milieu Ltd and Risk and Policy Analysis Ltd (2009) iv.

${ }^{48}$ Hassell and others (2010) 24.

${ }^{49}$ US EPA Office of Inspector General (2008a) 3. 
become members. Separating the factors that caused them to join from the influence of the voluntary program itself is difficult. ${ }^{50}$ Only rarely do governments establish a baseline of performance before the program begins. While some programs collect information on participants' environmental performance over time-tracking changes in their releases of greenhouse gases, for example-comparable information is rarely available for non-participants. ${ }^{51}$ Nevertheless, some researchers have begun to tackle the evaluation challenges using statistical analyses of how participation affects behavior and certain measures of environmental outcomes.

\section{Experience in developed countries}

The overall account of voluntary programs' impacts on environmental performance is modest and mixed. One of US EPA's earliest voluntary programs, the 33/50 program, has been the subject of numerous empirical studies. Khanna and Damon found that participation in US EPA's 33/50 program resulted in reductions in toxic releases of about 28 percent during the program's first three years. ${ }^{52}$ Innes and Sam assessed the program over multiple years and also found that the program reduced emissions, but primarily during 1991 and $1992 .{ }^{53}$ Vidovic and Khanna, however, found that firms made most of the reductions attributed to the program in the years prior to its inception, suggesting that members joined in order to claim credit for actions already taken.$^{54}$ Undertaking a more detailed analysis, Gamper-Rabindran concluded that the program's impact varied by industry. In the chemical industry, for example, the beneficial impacts noted in previous studies disappeared when two ozone-depleting chemicals were removed from the analysis - as firms were required to phase out these chemicals under binding rules called for in the Montreal Protocol. ${ }^{55}$

Voluntary programs appear to work best under threat of looming mandatory regulation. Prior to launching the 33/50 program, US EPA had announced plans to regulate most of the chemicals included in this program under the federal Clean Air Act's Maximum Available Control Technology (MACT) standards. By joining this program, firms were able to reduce emissions of these chemicals in their own way, at their own pace, while receiving recognition and technical assistance from US EPA. Firms in states with strong environmental group membership had greater reductions of 33/50 chemicals, perhaps because the threat of mandatory regulation was higher in those states. ${ }^{56}$

\footnotetext{
${ }^{50}$ Borck and Coglianese (2009) 310-312 (1996); US EPA (1999).

${ }^{53}$ Innes and Sam (2008) 292.

${ }^{54}$ Vidovic and Khanna (2007) 192.

${ }^{55}$ Gamper-Rabindran (2006).

${ }^{56}$ Maxwell and others (2000).
}

${ }^{51} \mathrm{Ibid}$; see also Morgenstern and Pizer (2007) 179-181.

${ }^{52}$ Khanna and Damon (1999). US EPA ended the program in 1996, declaring that emissions of the program's 17 targeted chemicals had declined by 50 percent. Johnson 
Improvements that can be attributed solely to voluntary programs tend to be small - nearly indistinguishable in most cases from what might well have happened anyway in the absence of these programs. Most of the gains attributed to US EPA's Strategic Goals Program were achieved prior to the program's start date; only water discharges fell continuously throughout the life of the program. ${ }^{57}$ The effect of US EPA's Climate Wise program on participant behavior appears to have been temporary - just for at most one to two years. ${ }^{58}$ In both cases, the incentives US EPA offered for joining these programs appear to have been insufficient to affect participants' behavior. (When surveyed, participants in US EPA's Performance Track program considered the rewards of that program to be quite small. ${ }^{59}$ ) Studies of the US Climate Challenge found no difference between emissions reductions of participants and non-participants, although some evidence suggests that late joiners were free-riding on the contributions of those who joined early ${ }^{60}$ A study of implementation of voluntary programs in OECD countries concluded that, in most cases, factors other than the voluntary program were likely responsible for any observed improvements in environmental performance. ${ }^{61}$

In some cases, faulty implementation by governmental agencies have been said to have undermined programs' effectiveness. In assessing US EPA's Project $\mathrm{XL}$, Marcus and his coauthors observed numerous practical impediments to cooperation, including ambiguity in US EPA's definition of "superior environmental performance" (a requirement for US EPA to grant regulatory flexibility, the program's primary benefit), differences in parties' goals, and technical, economic, and legal uncertainties. ${ }^{62}$ Facing complaints from participating businesses over the amount of time required to negotiate agreements - on average more than 20 months - as well as concerns from environmental advocacy organizations about the potential for environmental laxity by companies granted flexibility under the program, US EPA stopped accepting new Project XL proposals in 2003. ${ }^{63}$ Results of US EPA's Common Sense Initiative (CSI) show that it too fell far short of its ambitious goals, due in large measure to the requirement that parties reach agreement through consensus ${ }^{64}$ And participants in the US Department of Energy's (DOE) Voluntary Greenhouse Gas Registry have been said to have engaged in "highly selective reporting," increasing emissions while reporting reductions. ${ }^{65}$ Failure by US DOE to engage in more careful monitoring of participants' performance apparently allowed members to shirk program responsibilities.

\footnotetext{
${ }^{57}$ Johnson (2006) 182.

${ }^{58}$ Morgenstern and others (2007) 135.

${ }^{59}$ Abt Associates (2007) 24.

${ }^{60}$ Delmas and Montes-Sancho (2007); Welch and others (2000).

${ }^{61}$ OECD (2003).

${ }^{62}$ Marcus and others (2002).

${ }^{63}$ Klyza and Sousa (2013).

${ }^{64}$ Coglianese and Allen (2005).

${ }^{65} \mathrm{Kim}$ and Lyon (2011) 312.
} 
The US EPA's own analysis of its suite of voluntary programs presents a mixed picture. US EPA's Office of Inspector General reviewed the agency's partnership programs numerous times during the years $2005-2008 .{ }^{66}$ In a report issued in 2006, the Inspector General optimistically indicated that partnership programs such as Performance Track, Climate Leaders, WasteWise, and Energy Star had the potential to expand the agency's environmental influence by reaching participants who do not typically interact with US EPA and by addressing environmental problems not governed by regulations. But later that same year, the Inspector General's analysis of US EPA's "flagship" voluntary program, Performance Track, found that some participants in the "leadership" program actually exceeded the sector average for both regulatory violations and toxic releases, and that many Performance Track participants did not meet the commitments they made to US EPA under the program. ${ }^{67} \mathrm{~A}$ subsequent review of voluntary programs targeting greenhouse gases in 2008 found that, despite recruitment efforts, too few firms were choosing to join these programs to achieve meaningful emissions reductions. ${ }^{68}$

Voluntary programs aimed at improving the environmental performance of products have received less attention by social scientists. The US EPA's Inspector General reviewed the Energy Star program annually in the years 2007 through 2010, finding that US EPA and US DOE had failed during that period to set clear qualifying standards for products bearing the Energy Star label and had relied on manufacturers to self-certify that products met government criteria. ${ }^{69}$ A 2010 report by the US Governmental Accountability Office on Energy Star raised similar concerns. ${ }^{70}$ US EPA and US DOE have subsequently tightened Energy Star certification procedures. Clearly additional research is both possible and needed on this program as with others.

\section{Experience in developing countries}

In developing countries, governments often lack the funding, know-how, and even political will to develop and implement meaningful, mandatory environmental regulations. ${ }^{71}$ Many firms are small, unlicensed, and difficult to monitor. ${ }^{72}$ A growing number of researchers are exploring the potential for voluntary programs to fill gaps in government and private sector capacities in these countries.

Research suggests that firms in developing countries join voluntary programs to reduce the cost of regulatory compliance and appeal to customers and

\footnotetext{
${ }^{66}$ US EPA Office of Inspector General (2005); (2006); (2007a); (2008a).

${ }^{67}$ US EPA Office of Inspector General (2007a) 18-19.

${ }^{68}$ US EPA Office of Inspector General (2008a) 5-7.

${ }^{69}$ US EPA Office of Inspector General (2007b); (2008b); (2009); (2010).

${ }^{70}$ US GAO (2010)

${ }^{71}$ McAllister and others (2010) 2.

${ }^{72}$ Blackman (2010) 1.
} 
interest groups - the same motivations for firms in developed countries. ${ }^{73}$ These drivers are weaker in developing countries, though, where regulatory agencies lack the resources they need to exert significant pressure, and where market pressures for "green" practices and products remain relatively limited. ${ }^{74}$

In developed economies, voluntary programs serve mostly to encourage firms to improve their environmental performance beyond what regulations require. However, studies in Mexico ${ }^{75}$ and Colombia ${ }^{76}$ find little support that voluntary programs lead to environmental performance improvement in the developing world. For example, although Mexican regulators chose a public voluntary program to address pollution from the Mexican tanning industry because of gaps in regulatory, public, and civic infrastructure that rendered mandatory regulations futile, those same gaps undermined the effectiveness of the voluntary program. ${ }^{77}$

Instead of seeking to induce beyond-compliance improvements in environmental performance, developing countries have sometimes pursued voluntary programs simply to reduce noncompliance with mandatory rules. ${ }^{78}$ Mexico's Clean Industry Program exemplifies this approach. In order to participate, firms must hire third-party auditors to identify areas of non-compliance with environmental regulations and work with government to develop a plan to achieve compliance. Upon completion of the plan, the government awards participating facilities with "clean industry certificates" that entitle members to inspection amnesty for two years. ${ }^{79}$ The program tended to attract larger, dirtier plants that were subject to regulatory fines before joining the program. These plants were more likely to sell products to overseas markets and government suppliers than nonmembers, and may have been subject to greater competitive pressures. ${ }^{80}$ After the two-year amnesty period elapsed, members and non-members were equally likely to be subject to regulatory fines, which might be a positive result if the member plants were more likely to experience violations in the absence of the program. ${ }^{81}$

Chile has negotiated agreements with firms in a variety of sectors as part of a national policy to improve regulatory compliance. Researchers attribute the success of the program to Chile's relatively robust environmental regulatory program and the fact that the agreements included clear targets and deadlines, monitoring by industry trade associations, and sanctions for non-compliance. ${ }^{82}$

\footnotetext{
${ }^{73}$ Khanna and Liao (2014) 148.

${ }^{74}$ Blackman (2010) 2.

${ }^{75}$ Blackman and Sisto (2006).

${ }^{76}$ Blackman and others (2009).

${ }^{77}$ Blackman and Sisto (2006) 1041.

${ }^{78}$ Blackman and others (2010) 182.

${ }^{79}$ Ibid 183.

${ }^{80}$ Ibid 191.

${ }^{81}$ Ibid.

82 Jimenez (2007) 620-621.
} 


\section{Impacts of ISO 14001 adoption}

Up to now, we have focused solely on voluntary programs adopted and implemented by government authorities. Other voluntary programs have been established by trade associations and nongovernmental organizations, and the lessons from these programs may well be instructive about the potential for governments to achieve environmental gains without regulatory mandates. Some government programs have even supported or encouraged participation in nongovernmental voluntary programs or have been at least partly modeled on them.

ISO 14001 is perhaps the most well-known and extensively studied private voluntary approach to environmental management. Facilities that comply with ISO 14001's voluntary standards must establish internal environmental management systems (EMSs) through which managers identify the environmental impacts of their operations, develop goals to reduce those impacts, check progress toward achieving their goals, and take corrective action when progress falls short. To meet ISO's standards, facilities must develop an environmental policy that calls for compliance with regulations and continuous improvement. Facilities can become certified to ISO 14001 by having a registered third party verify that their environmental management system is consistent with the standard.

Firms that adopt ISO 14001 appear to be motivated by the same factors as firms that adopt voluntary programs - they tend to be larger polluters and sell products directly to consumers. ${ }^{83}$ A few studies have found statistically significant positive results associated with facility adoption of the kind of environmental management systems called for under ISO 14001. Darnall and Kim found that firms that adopted EMSs reported levels of environmental performance relatively better than non-adopters. ${ }^{84}$ Another study suggests that facilities that certify to ISO 14001 may be more likely to monitor the environmental performance of suppliers. ${ }^{85}$ And Prakash and Potoski, in one the most sophisticated investigations to date, found that ISO 14001 certification was associated with facilities spending less time out of compliance as well as with some decreases in toxic releases. ${ }^{86}$ Even so, the impacts of ISO certification tend to be substantively small. The ISO-certified facilities in Prakash and Potoski's study, for example, were on average out of compliance only one week less than other facilities and, as Prakash and Potoski acknowledge, their findings on toxic releases were "difficult to interpret" and reflected "not a very large improvement."87

\section{Conclusion}

Governments around the world have adopted voluntary environmental programs since the mid-1980s. With the passage of time, a number of these programs have been studied to understand their effectiveness, which will generally

${ }^{83}$ Anton and others (2004).

${ }^{84}$ Darnall and Kim (2012).

${ }^{85}$ Arimura and others (2011).

${ }^{86}$ Potoski and Prakash (2006) 146-170.

${ }^{87}$ Ibid 166; see also Coglianese (2008). 
be understood to be a function both of the number of firms that choose to join the program and the impact of the program on the participants. Both modeling and empirical evidence suggests that firms join these programs to reduce the costs of complying with regulation, to appeal to customers, and to respond to internal organizational factors. The design of these programs also appears to matter; those that offer the most benefits also impose the greatest requirements for entry and ongoing participation-and tend, perhaps counter-intuitively, to attract the fewest participants. Overall, participation in voluntary environmental programs is limited to a very small fraction of businesses that contribute to environmental concerns.

When it comes to discerning effects of voluntary programs on business behavior and environmental impacts, a few studies suggest that some programs are associated with statistically significant improvements, but overall even these effects tend to be very modest. When voluntary programs do seem to work best, it appears they do so because they are reinforced by the presence of strong community pressures and regulatory threats. Despite the allure of having government motivate business without adopting mandates, it appears that not only are voluntary programs unlikely to substitute for regulations, but also that whatever minor impacts they have depends on the existence of mandates lurking in the background. At most, the role for voluntary programs appears to be as a modest supplement to government regulation.

\section{References}

Abt Associates, Results of the 2006 Performance Track Members Survey (2007) (on file with the authors)

Anton WRQ and others, 'Incentives for Environmental Self-Regulation and Implications for Environmental Performance' (2004) 48 J Envtl Econ and Mgmt 632

Antweiler W and Harrison K, 'Toxic Release Inventories and Green Consumerism: Empirical Evidence from Canada' (2003) 36 The Canadian Journal of Economics 495

Arimura TH and others, 'Is ISO 14001 a Gateway to More Advanced Voluntary Action? The Case of Green Supply Chain Management' (2011) 61 J Envtl Econ and Mgmt 170

Arora S and Cason TN, 'An Experiment in Voluntary Environmental Regulation: Participation in EPA's 33/50 Program' (1995) 28 J Envtl Econ and Mgmt 271

'Why Do Firms Volunteer to Exceed Environmental Regulations? Understanding Participation in EPA's 33/50 Program' (1996) 72 Land Econ 413

Arora S and Gangopadhyay S, 'Toward a Theoretical Model of Voluntary Overcompliance' (1995) 28 J Econ Behavior and Org 289

Blackman A, 'Alternative Pollution Control Policies in Developing Countries' (2010) 4 Rev Envtl Econ and Policy 1 
Blackman A and others, 'Voluntary Environmental Agreements in Developing Countries: The Colombian Experience' (2009) (Resources for the Future Report)

'Voluntary Economic Regulation in Developing Countries: Mexico's Clean Industry Program' (2010) $60 \mathrm{~J}$ Envtl Econ and Mgmt 182

Blackman A and Sisto N, 'Voluntary Environmental Regulation in Developing Countries: A Mexican Case Study' (2006) 46 Natural Resources J 1005

Borck JC and Coglianese C, 'Voluntary Environmental Programs: Assessing Their Effectiveness' (2009) 34 Annual Rev Envt and Resources 305

Boyd J and others, 'Intel's XL Permit: A Framework for Evaluation' (1998) (Resources for the Future Discussion Paper 98-11)

Chittock DG and Hughey KFD, 'A Review of International Practice in the Design of Voluntary Pollution Prevention Programs' (2011) 19 J Clean Prod 542

Coglianese C, 'Review of The Voluntary Environmentalists: Green Clubs, ISO 14001, and Voluntary Environmental Regulations by Aseem Prakash and Matthew Potoski' (2008) 42 Law \& Soc'y Rev 932

Coglianese C and Allen LK, 'Building Sector-Based Consensus: A Review of the US EPA's Common Sense Initiative' in Theo de Bruijn and Vicki NorbergBohm (eds), Industrial Transformation: Environmental Policy Innovation in the United States and Europe (MIT Press 2005)

Coglianese C and Nash J, 'Environmental Management Systems and the New Policy Agenda' in Cary Coglianese and Jennifer Nash (eds), Regulating from the Inside: Can Environmental Management Systems Achieve Policy Goals? (Resources for the Future Press 2001)

'Performance Track's Postmortem: Lessons from the Rise and Fall of EPA's “Flagship” Voluntary Program' (2014) 38 Harv Envtl L Rev 1

Darnall N and Carmin J, 'Greener and Cleaner? The Signaling Accuracy of U.S. Voluntary Environmental Programs' (2005) 38 Policy Sciences 71

Darnall N and Kim Y, 'Which Types of Environmental Management Systems Are Related to Greater Environmental Improvements?' (2012) 72 Pub Admin Rev 351

Darnall N and others, 'Sponsorship Matters: Assessing Business Participation in Government- and Industry-Sponsored Voluntary Environmental Programs' (2009) 20 J Pub Admin Research and Theory 283

Davies $\mathrm{T}$ and Mazurek J, Industry Incentives for Environmental Improvement: Evaluation of U.S. Federal Initiatives (1996) (Global Environmental Management Initiative)

Delmas M and Keller A, 'Free Riding in Voluntary Environmental Programs: The Case of the U.S. EPA WasteWise Program' (2005) 38 Policy Sciences 91

Delmas MA and Montes-Sancho MJ, 'Voluntary Agreements to Improve Environmental Quality: Symbolic and Substantive Cooperation' (2010) 31 Strategic Mgmt J 575

Esty DC and Winston AS, Green to Gold: How Smart Companies Use Environmental Strategy to Innovate, Create Value, and Building Competitive Advantage (Yale University Press 2006) 
Fiorino D 'Rethinking Environmental Regulation: Perspectives on Law and Governance' (1999) 23 Harv Envtl L Rev 441

The New Environmental Regulation (MIT Press 2006)

Gamper-Rabindran S, 'Did the EPA's Voluntary Industrial Toxics Program Reduce Plants' Emissions? A GIS Analysis of Distributional Impacts and a By-Media Analysis of Substitution' (2006) 52 J Environ Econ Manag 391

Glachant $M$ and de Muizon G, 'Climate Change Agreements in the United Kingdom: A Successful Policy Experience?' in Richard D. Morgenstern and William A. Pizer (eds), Reality Check: The Nature and Performance of Voluntary Environmental Programs in the United States, Europe, and Japan (Resources for the Future 2007)

Gunningham N and others, Shades of Green: Business, Regulation, and Environment (Stanford Law and Politics 2003)

Hassell S and others, An Assessment of the U.S. Environmental Protection Agency's National Environmental Performance Track (RAND ISE 2010)

Howard-Grenville $\mathrm{J}$ and others, 'Constructing the License to Operate: Internal Factors and Their Influence on Corporate Environmental Decisions (2006) 30 Law \& Soc'y Rev 73

Innes R and Sam AG, 'Voluntary Pollution Reductions and the Enforcement of Environmental Law: An Empirical Study of the 33/50 Program' (2008) $51 \mathrm{~J}$ L and Econ 271

Jiménez O, 'Voluntary Agreements in Environmental Policy: An Empirical Evaluation for the Chilean Case' (2007) 15 J Cleaner Production 620

Johnson J. 33/50 Program Ends, EPA Declares Success (1996) 30 Environ Sci Technol 482A

Johnson JS, 'The Promise and Limits of Voluntary Management-Based Regulatory Reform: An Analysis of EPA's Strategic Goals Program' in Cary Coglianese and Jennifer Nash (eds), Leveraging the Private Sector: Management-Based Strategies for Improving Environmental Performance (Resources for the Future 2006)

Khanna M and Damon LA, 'EPA's Voluntary 33/50 Program: Impact on Toxic Releases and Economic Performance of Firms' (1999) 37 J Envtl Econ and Mgmt 1

Khanna M and Liao Y, 'Globalization and Voluntary Environmental Management in Developing Countries' (2014) 9 Front Econ China 138

Kim E-H and Lyon TP, 'Strategic Environmental Disclosure: Evidence from the DOE's Voluntary Greenhouse Gas Registry' (2011) 61 J Environ Econ Manag 311

Klyza CM and Souza DJ, American Environmental Policy: Beyond Gridlock (MIT Press 2013)

Kraprup S and Millock K, 'Evaluation of the Danish Agreements on Industrial Energy Efficiency' in Richard D Morgenstern and William A Pizer (eds), Reality Check: The Nature and Performance of Voluntary Environmental Programs in the United States, Europe, and Japan (Resources for the Future 2007) 
Lutz S and others, 'Quality Leadership when Regulatory Standards Are Forthcoming' (2000) 48 J Industrial Econ 331

Lyon TP and Maxwell JW, "Voluntary" Approaches to Environmental Regulation: A Survey' in Maurizio Franzini and Antonio Nicita (eds), Economic Institutions and Environmental Policy (Ashgate 2002)

'Environmental Public Voluntary Programs Reconsidered' (2007) 35 Policy Studies $J 723$

Marcus A and others, Reinventing Environmental Regulation: Lessons from Project $X L$ (Johns Hopkins University Press 2002)

Maxwell JW and others, 'Self-Regulation and Social Welfare: The Political Economy of Corporate Environmentalism' (2000) $43 \mathrm{~J}$ L and Econ 583

McAllister LK and others, 'Reorienting Regulation: Pollution Enforcement in Industrializing Countries' (2010) 32 L and Policy 1

Milieu Ltd and RPA (Risk and Policy Analysis Ltd), 'Study on the Costs and Benefits of EMAS to Registered Organisations' (2009) (Final Report for DG Environment of the European Commission)

Morgenstern RD and Pizer WA, 'Concluding Observations' in Richard D Morgenstern and William A Pizer (eds), Reality Check: The Nature and Performance of Voluntary Environmental Programs in the United States, Europe, and Japan (Resources for the Future 2007)

Morgenstern RD and others, 'Evaluating Voluntary U.S. Climate Programs: The Case of Climate Wise' in Richard D Morgenstern and William A Pizer (eds), Reality Check: The Nature and Performance of Voluntary Environmental Programs in the United States, Europe, and Japan (Resources for the Future 2007)

Nash J, 'Tiered Environmental Regulation: Lessons from the StarTrack Program' in Theo de Bruijn and Vicki Norberg-Bohm (eds), Industrial Transformation: Environmental Policy Innovation in the United States and Europe (MIT Press 2005)

Orts EW, 'Reflexive Environmental Law' (1995) 89 Nw. U L Rev 1227

Prakash A and Potoski M, The Voluntary Environmentalists: Green Clubs, ISO 14001, and Voluntary Environmental Regulations (Cambridge University Press 2006)

OECD (Organisation for Economic Co-operation and Development), Voluntary Approaches for Environmental Policy: Effectiveness, Efficiency and Usage in Policy Mixes (OECD Publishing 2003)

Segerson K and Li N, 'Voluntary Approaches to Environmental Protection' in Henk Folmer and Tom Tietenberg (eds), The International Yearbook of Environmental and Resource Economics 1999/2000: A Survey of Current Issues (Edward Elgar 2000)

Segerson K and Miceli TJ, 'Voluntary Environmental Agreements: Good or Bad News for Environmental Protection?' (1998) 36 J Envtl Econ and Mgmt 109

Thaler RH and Sunstein CR, Nudge: Improving Decisions about Health, Wealth, and Happiness (Penguin 2008)

US EPA (Environmental Protection Agency), Environmental Investments: The Cost of a Clean Environment: A Summary (1990) (EPA-230-12-90-084) 
Office of Pollution Prevention and Toxics, 33/50 Program: The Final Record (1999) (EPA-745-R-99-004)

- FY 2015: EPA Budget in Brief (2014) (EPA-190-S-14-001)

— Office of Atmospheric Programs, Climate Protection Partnerships: 2013 Annual Report (2015) (EPA-430-R-13-013)

US EPA Inspector General, Ongoing Management Improvements and Further Evaluation Vital to EPA Stewardship and Voluntary Programs (2005) (Inspector General Evaluation Report No 2005-P-00007)

— Partnership Programs May Expand EPA's Influence (2006) (Inspector General Evaluation Report No 2007-P-00003)

_ Performance Track Could Improve Program Design and Management to Ensure Value (2007a) (Inspector General Evaluation Report No 2007-P00013)

_ ENERGY STAR Program Can Strengthen Controls Protecting the Integrity of the Label (2007b) (Inspector General Evaluation Report No 2007-P-00028)

— Voluntary Greenhouse Gas Reduction Programs Have Limited Potential (2008a) (Inspector General Evaluation Report No 08-P-0206)

_ Improvements Needed to Validate Reported ENERGY STAR Benefits (2008b) (Inspector General Evaluation Report No 09-P-0061)

— ENERGY STAR Program Integrity Can Be Enhanced Through Expanded Product Testing (2009) (Inspector General Evaluation Report No 10-P-0040)

— ENERGY STAR Label Needs to Assure Superior Energy Conservation Performance (2010) (Inspector General Evaluation Report No 11-P-0010)

US Government Accountability Office, Covert Testing Shows the Energy Star Program Certification Process Is Vulnerable to Fraud and Abuse (2010) (Government Accountability Office Report No GAO-10-470)

Videras J and Alberini A, 'The Appeal of Voluntary Environmental Programs: Which Firms Participate and Why?' (2000) 18 Contemporary Econ Policy 449

Vidovic M and Khanna N, 'Can Voluntary Pollution Prevention Programs Fulfill Their Promises? Further Evidence from the EPA's 33/50 Program' (2007) 53 $J$ Envtl Econ and Mgmt 180

Welch EW and others, 'Voluntary Behavior by Electric Utilities: Levels of Adoption and Contribution of the Climate Challenge Program to the Reduction of Carbon Dioxide' (2000) 19 J Policy Anal Manag 407 